\title{
THE VALUE OF LIVING COLLECTION CATALOGUES AND CATALOGUES PRODUCED FROM THE ROYAL BOTANIC GARDEN EDINBURGH
}

\author{
David Rae
}

\begin{abstract}
Many botanic gardens produce catalogues of plants growing in their gardens on either a regular or ad hoc basis. These catalogues are useful for reference and archive purposes and their production has added benefits such as the necessity to stocktake the collection and clarify nomenclature prior to publication. Many now also contain interesting introductory material such as collection statistics, histories of the gardens and information about significant plants in the collection. This paper describes the value of producing catalogues, reviews four diverse approaches to catalogues (from the Arnold Arboretum, Ness Botanic Gardens, Oxford Botanic Garden and Utrecht Botanic Garden) and then describes the catalogues produced by the Royal Botanic Garden Edinburgh, before culminating in a description of Edinburgh's 2006 Catalogue.
\end{abstract}

\section{INTRODUCTION}

Catalogues of botanic garden living collections have been produced in numerous sizes, shapes and formats for many years and consist of lists of plants growing in the gardens concerned for a particular year. They are very useful for reference and archive purposes and serve as a helpful source of information about plants in a collection. They should not be confused with Indices Seminum which are seed lists issued by many botanic gardens (see Aplin et al., 2007) or herbarium catalogues which are, as their name suggests, listings of herbarium specimens held in various herbaria. Some botanic gardens issue catalogues on a regular basis while others produce them infrequently, often in conjunction with a special anniversary. In some cases botanic gardens issue catalogues of particular parts or sections of their collections such as plants from a certain country or continent, plants collected by a specific person or types of plants in the collection such as trees, bulbs or herbaceous plants. While the early catalogues usually contained only plant lists with no additional information, more recent catalogues are tending to provide introductory information such as the history of their garden and collection statistics and then further information adjacent to each taxon such as accession number, collector code and number, and location within the garden.

\section{VALUE OF PRODUCING A CATALOGUE OF THE LIVING COLLECTION}

With the increasing use of the World Wide Web and internet some might query the need for a printed 'Catalogue of Plants'. After all, a printed catalogue is relatively expensive

${ }^{1}$ David Rae is Director of Horticulture at the Royal Botanic Garden Edinburgh.

Address: Royal Botanic Garden Edinburgh, 20A Inverleith Row, Edinburgh EH3 5LR.

Email: d.rae@rbge.org.uk 
and out of date from the moment it is published. A web version, on the other hand, can be updated easily and regularly and is accessible world-wide at any time. There are, however, some important advantages in having a printed version. Not least of these is the fact that it helps focus staff on important preparatory activities such as detailed stocktaking of the living plants and ensuring that the most up-to-date names are being used. Both are necessary, but time consuming and frequently neglected, plant recording tasks. Stocktaking (also known as 'ground truthing') has the value of ensuring that the plants listed in a database really do exist outside on the ground. If this task is not undertaken on at least a moderately regular basis (e.g. every 3-5 years) then no one, neither staff nor visitors, can have confidence in any database records. The imminent production of a catalogue is a very useful reminder to staff to ensure that their section or area of the garden has had a recent stocktake. The same can be said of up-to-date nomenclature, not to mention correct spelling. No garden would wish to use 'old' or incorrect names or synonyms and, again, the imminent production of a catalogue is a very useful moment to check naming against the most recent monographs or floras. Other important reasons include the archival value, the ease of referring to the contents in a garden situation and the inclusion of other very useful facts and figures contained in the introductory pages. Ideally, a botanic garden should have both web and printed versions, with each complementing the other. The Royal Botanic Garden Edinburgh (RBGE) believes in such an approach and the web version (which is not quite as comprehensive as the printed Catalogue) can be found at http://www.rbge.org.uk/rbge/web/search.cat.jsp

\section{REVIEW OF CATALOGUES}

A visual review of the shelves containing living collection catalogues at the Library of RBGE revealed a vast array of publications, both large and small and old and new. A selection of interesting and varied examples includes those from the Arnold Arboretum of Harvard University, Ness Botanic Gardens, University of Oxford Botanic Garden and University of Utrecht Botanic Garden, which are described below.

The Library at Edinburgh has four copies of the Arnold's Catalogue, correctly titled Plant Inventory, for the years 1990, 1992, 1996 and 2003. The 2003 Inventory (Living Collections Department of the Arnold Arboretum, 2003) (see Fig. 1) starts with five pages of text covering a brief history of the collection, some statistics, information on plant labels, location and altitude of the Arnold Arboretum, how to use the Inventory and availability of propagation materials. The Inventory itself lists taxa alphabetically by genus and then species within genus and, for each accession of the given taxon, the following information is given: accession number, country of origin (if wild collected), Arnold Arboretum map location(s) and herbarium specimen (if collected). The Inventory concludes with an index to families, index to common names and maps of the Arboretum.

Index Nessensis, Catalogue of the Plant Collections at Ness Botanic Gardens, was produced in 1998 to celebrate the centenary of Ness, founded in 1898 by Arthur 


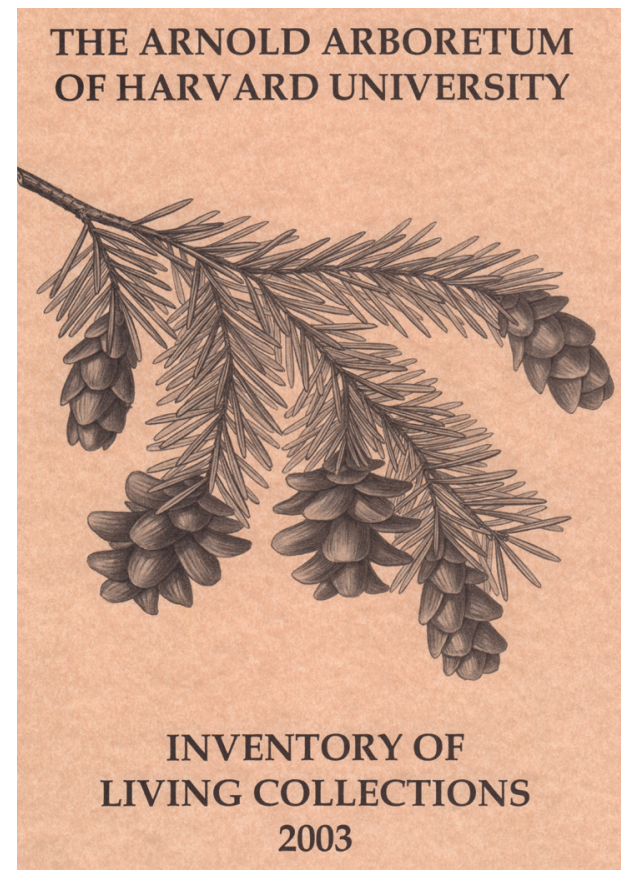

Fig. 1 Front cover of the Arnold Arboretum's Inventory of Living Collections 2003.

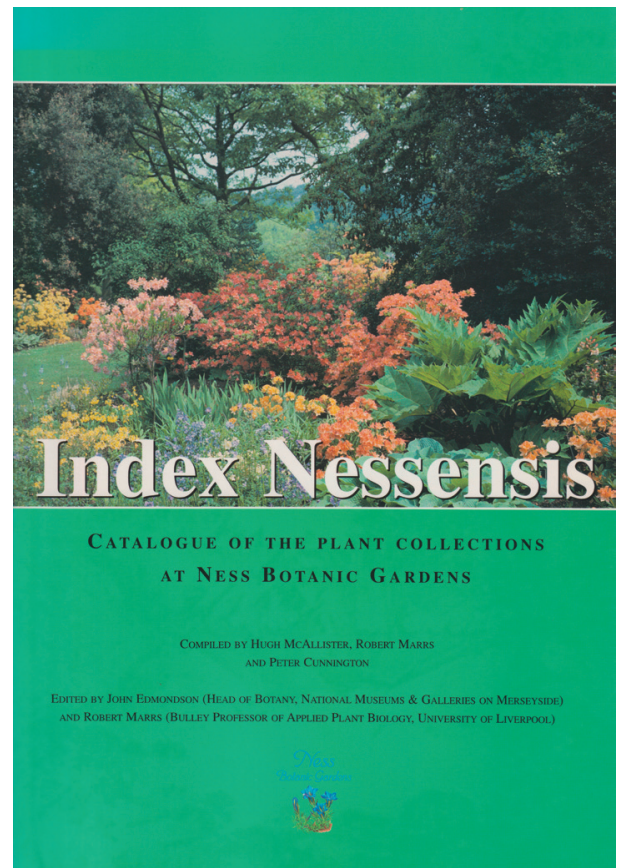

Fig. 2 Front cover of Ness Botanic Gardens’ 1998 Catalogue.

Kilpin Bulley (McAllister et al., 1998) (see Fig. 2). It starts with a brief history of Ness Botanic Gardens including information about Bulley, links to the great plant hunters, the University of Liverpool connection, information about the living collections, cataloguing the collection and a table containing brief biographies of some of the plant collectors who have provided seeds or plants for Ness. After a 'Guide to the Index' the listings themselves are presented in systematic order and include name, origin ( W - wild, $\mathrm{G}$ - garden origin or Z - of garden origin, but from material of known wild origin), collector and collector code, location, altitude and number (a unique reference number, essentially an accession number). The Index concludes with an index to families and index to genera.

A catalogue of the plants growing in the University of Oxford Botanic Garden and Harcourt Arboretum, published in 1999, was the first entirely new catalogue to be published from Oxford for 350 years (University of Oxford, 1999) (see Fig. 3). The first, fully titled Catalogus Plantarum Horti Medici Oxoniensis was published in 1648 by Henry Hall, printer to the University. The list contained 1,600 different plants, all of which had been amassed in just six years by Jacob Bobart, first Horti Praefectus of the Garden (while the Garden was founded in 1621 planting only started in 1642). Interestingly, the 1999 Catalogue contains a facsimile of the 1648 list. In 1658 an improved and updated catalogue was published by Philip Stephens and William Browne, two of the most respected botanists at Oxford. 


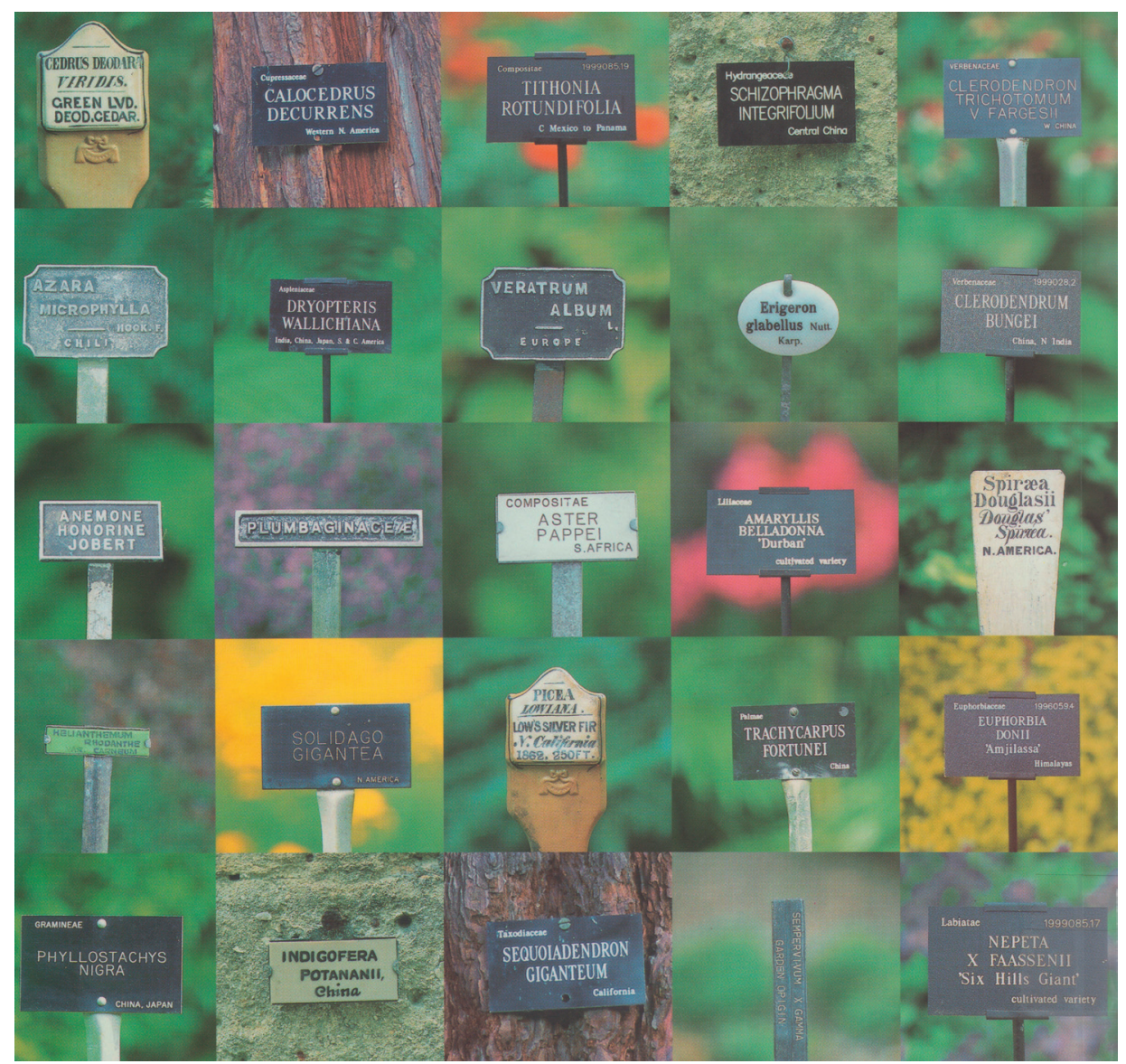

Fig. 3 Front cover of the University of Oxford Botanic Garden and Harcourt Arboretum Catalogue, 1999.

The Catalogue starts with 15 pages of history, explanation and maps. These are followed by the facsimile of the 1648 Catalogus and then the 1999 Catalogue. While the 1648 Catalogus (see Figs. 4, 5) lists plants alphabetically by genus the 1999 Catalogue lists plants arranged in their botanical groupings - ferns and their allies, then conifers and their allies and finally, flowering plants. Within each group families, then genera and species are listed alphabetically. Information at the start of each family includes a numerical synopsis of the family listing number of genera, species and taxa in the family. After this each taxon lists accession number and location within the Garden or Arboretum. The Catalogue concludes with an index to families and genera.

The Utrecht University Catalogue of Plant Collections, 1992 (Wollenberg et al., 1992) (see Fig. 6) appears to be the most recent catalogue produced by the Garden with the previous one dating from 1986. In the introduction it notes that since the publication of the previous Catalogue in 1986, the Garden has seen many major changes. Five 


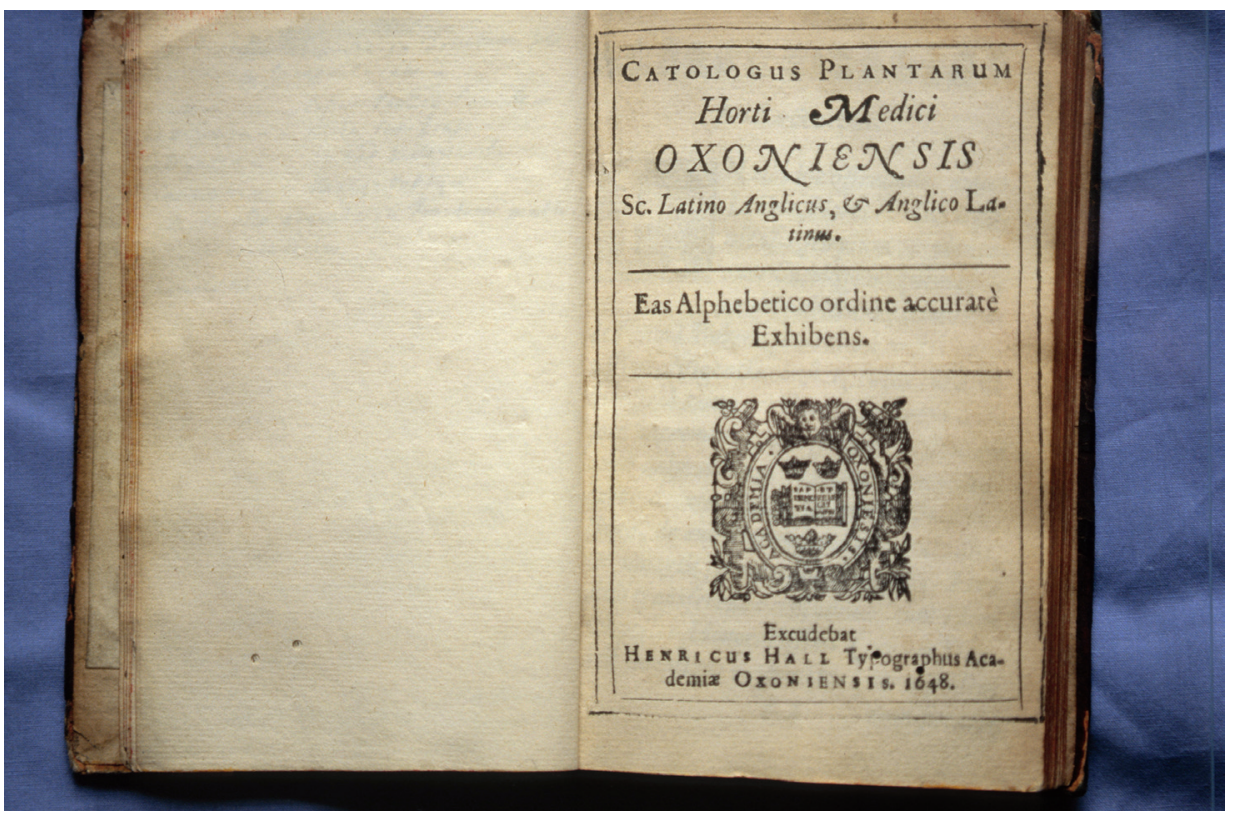

Fig. 4 Front page of Catalogus Plantarum Horti Medici Oxoniensis, 1648.

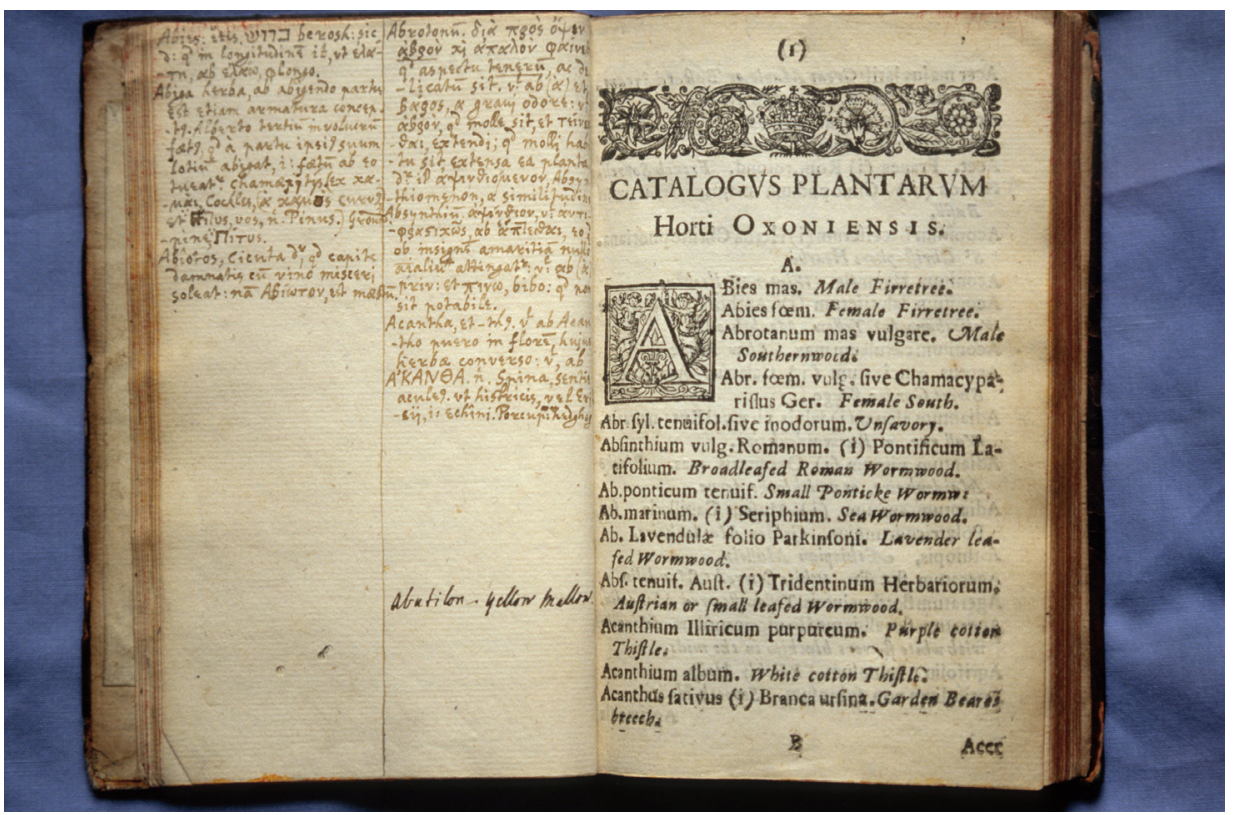

Fig. 5 First page of catalogue listings in Catalogus Plantarum Horti Medici Oxoniensis, 1648. 


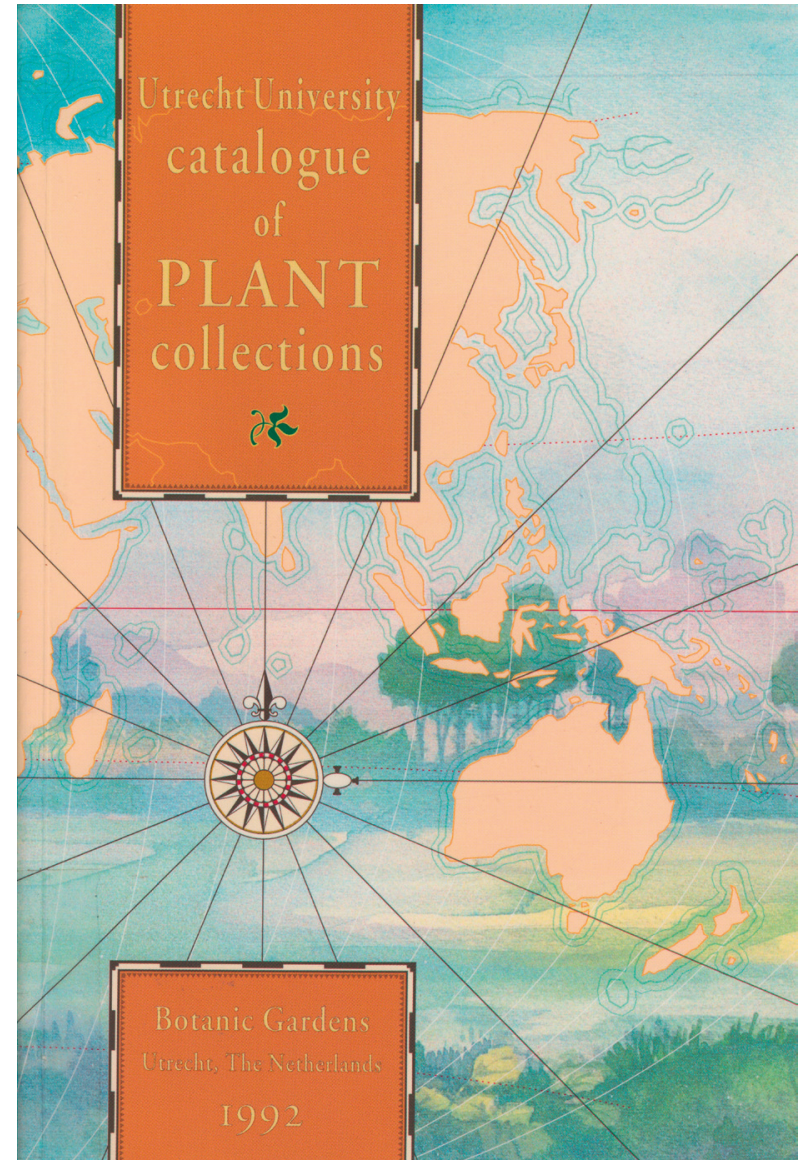

Fig. 6 Front cover of the Utrecht University Catalogue of Plant Collections, 1992.

out of the six satellite gardens have been brought together into one main garden, Fort Hoofddijk in the University Centre 'DeUithof', leaving only one satellite garden, the Von Gimborn Arboretum. This centralization was completed by 1991 and the Catalogue lists plants from both sites. After this introduction there are 46 pages of information and photographs. These start with a chapter on Utrecht Botanic Gardens: organisation and activities. Under 'History' it is interesting to note that the Garden was established in 1639 and as early as 1650 Henrius Regius (1598-1679), in his capacity as director, published the first garden catalogue. The collection at the time consisted of 678 species of predominantly medicinal and ornamental plants. The account concludes with subsections describing the present situation, organization, living collection and education before further subsections on future plans and the role of botanic gardens in conservation (the latter written by Professor Vernon Heywood, then Director General of Botanic Gardens Conservation International - BGCI). Chapter 2 covers a survey of projects and activities serviced by the Garden and living collection including scientific research projects, scientific educational projects and projects using the living collection by other 
university departments. Sections follow on other projects and include information about the Dutch Botanic Garden Foundation and the Decentralised National Plant Collection. Chapter 3 describes maintaining quality collections and includes subsections on topics such as documentation, labelling and the seedbank. Several pages of photographs of plants in the collection and new facilities follow.

The main part of the Catalogue starts with some explanation about the collection and then progresses into the Catalogue listings which are arranged alphabetically by family. Each entry starts with an accession number, then an identification code showing level of verification, then provenance type (for example $\mathrm{E}$ - wild source, $\mathrm{G}$ - from garden origin or $\mathrm{K}$ - from commercial grower). The next column lists World Conservation Monitoring Centre (WCMC) code (covering rarity/threat status) and then the taxon itself including authority, followed in square brackets by collector code and origin. The Catalogue concludes with five appendices and an index to generic and family names.

\section{CATALOGUES FROM THE ROYAL BOTANIC GARDEN EDINBURGH}

In 1683, James Sutherland, Intendant of the Physic Garden in Edinburgh, published Hortus Medicus Edinburgensis with the subtitle 'or, A Catalogue of Plants in the Physic

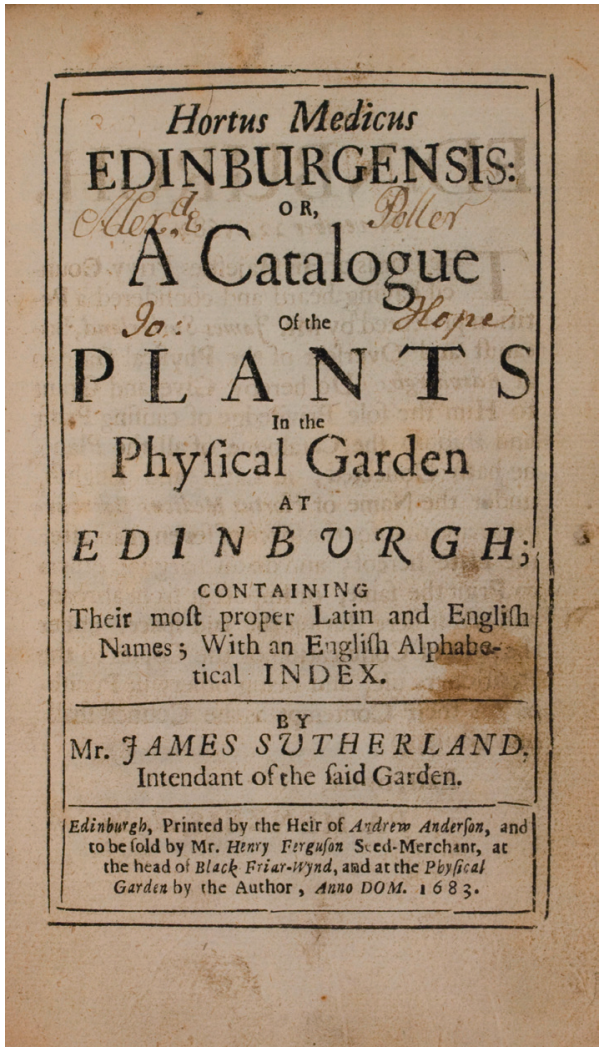

Garden at Edinburgh; containing Their most proper Latin and English names; With an English Alphabetical Index' (see Fig. 7). This was the first publication of its kind in Scotland and it signalled the Scottish entry into the established fraternity of European botanical gardens. In the remarks addressed to the reader, Sutherland asserted that the "Catalogue of plants growing in the garden could stand comparison with similar publications from foreign botanic gardens both in the number and rarity in the plants listed". During the seven years he had been in charge of the Garden, it had been his practice "to augment the diversity of plants by industry and correspondence with foreign botanists from the Levant, Italy, Spain, France, The Netherlands, England and both the East and West Indies, as well as by many

Fig. 7 Front page of James Sutherland's Hortus Medicus Edinburgensis, 1683. 
painful journeys in all season the year, to recover whatever this kingdom produceth of variety".

Sutherland drew particular attention to the medicinal significance of the Garden: "Many of the medicinal plants that were wanting here, and therefore yearly brought from abroad, because of their usefulness in Physick, may now by Industry and Culture be had in plenty at home. Before the establishment of the garden, the Apothecaries' Apprentices could never be competently instructed, as they should be, in the Knowledge of Simples. Now they can learn more in the space of one summer than it was formerly possible for them to do in an Age" (see Fig. 8).

Plants are presented alphabetically using the pre-Linnaean polynomial system of nomenclature. Each species listing includes a short description along with common names. The Catalogue also includes a comprehensive index of the English names of the species, as used by John Gerard (1633) and Parkinson. The species are also identified as either of 'Officinarum', i.e. for medical use, annual or found in Scotland. Robertson (2001) has done an analysis of the plants contained in the Catalogue and it shows that about $20 \%$ of the collection comprised officinal species, about $30 \%$ ornamentals and the rest were botanical species, of which $44.4 \%$ are identified as Scottish.

\section{The Ep̈iftle}

the truth of this, I hope thefe worthy Gentlemen who were named Overfeers to the Garden, will bear me Witnefs. Neither do I need here to trouble your Lordfhip with a rehearfal of the Advantages that from this Defign accrues to the whole Nation, and more efpecially to this Place, befides the Ornament thereof; for now it plainly appears that many of thefe Simples that were wanting here, and therefore ycarly brought from abroad, becaufe of their Ufefulnefs in Phy fick, may now by Indurt $y$ and Culcure be had in plenty at home. And it is evident that the Apothecaries Apprentices could never be competently inftructed in the Knowledge of Simples (whichneceffarly they ought to be) before the Eftablighing of this Garden; for now they may learn more in one Summer, then formerly it was polfible for them to do

\section{Dedicatory.}

in an Age. And to make the thing eafièr for Beginners, $I$ have Planted in One corner of the Garden, the Dilpenfatory Plants in an alphabetical Order. And for thofe whofe Curiofity and Time gives them further defire of learning Botanie, $I$ have difpofed the whole Plants according to the moft natural and rational Method, and according to the beft and lateft Authors of Botanie, and particularly our moft Learned and incomparable Countreyman Doctor Morifon, by their Ge: nera and Species; by means whereof, they come not only more eafily to be known, but alfo much better retained in Memary. I have given the Englifh Names as well as the Latin, that the Catalogue might be the more ufeful to all Perfons; and efpecially thofe that are unskilful in the Latin. And now, My Lord, fuch as it is, $I$ in all humble Duty, Dedicate and Offer it to your Lordfip, be-

Fig. 8 Text from the Preface of James Sutherland's Hortus Medicus Edinburgensis, 1683. 
More than 30 sources are listed in the bibliography to the Hortus indicating that the author drew on all the relevant botanical literature of the 16th and 17th centuries in the preparation of his book. Both in the inclusion of alternative definitions of species by different authors and in the general ordering of species, Sutherland followed the practice set out in Bauhin's Pinax. Sutherland included many of the Latin species descriptions and also the English names from both Gerard's The Herball or Generall Historie of Plants, as revised and enlarged by Thomas Johnson (1633), and Parkinson's A Paradise of Pleasant Flowers (1629) and also his Theatrum Botanicum (1640). Among the other authors quoted, the most notable include Jean Bauhin, brother of Gaspard (Historia Universalis Plantarum, 1650-51), Andrea Caesalpino (De Plantis libri XVI, 1583), Charles de l'Ecluse, better known as Clusius (Rariorum Plantarum Historia, 1605) and Rembert Dodoens (Stirpium Historiae Pemptades, 1583; a work better known simply as Pemptades, which was translated by Priest, without acknowledgement, and used as a basis for Gerard's Herbal). The bibliography also referred to John Ray (Catalogus Plantarum Angliae et Insulorum, 1670) and to John Rea's Flora: seu, de Florum Cultura (1665) (Robertson, 2001).

In 1712, Preston published the Garden's first catalogue since Sutherland's of 1683. No copies of this 1712 catalogue exist, but its second edition (1716) lists only some 568 taxa, a far cry from Sutherland's list of over 1,900 taxa, reflecting, no doubt, the problem caused by the Nor' Loch flooding ${ }^{1}$ and the subsequent uninspired leadership of the Garden by Sutherland in his latter days and by Charles Preston (Robertson, 2001).

In 1740 Charles Alson (1685-1760), appointed King's Botanist, Professor of Botany and Materia Medica and Overseer of the Royal Garden - or Regius Keeper in 1716, published an Index plantorum praecipus officinalium quae, in Horto Medico Edinburgensi. This is, essentially, a catalogue of medicinal plants growing in Edinburgh at the time. The Index listings which are titled Index plantarum officinalium start with lists of plants arranged by 'Classis' (e.g. Classis I, Classis II etc.), and was essentially the systematic arrangement of the day. It is then followed by the index of plants with common names. In 1753 he published a further book titled Titocinium botanicum Edinburgense which is basically the same but with more text and information before the Index (the Index itself is titled Index Plantarum Medicinalium).

In the Library archives there are three further catalogues from the 18th century. Catalogue of trees and shrubs growing in the Botanic Garden at Edinburgh is arranged alphabetically by genus and includes common names. There is no author name on the front page but it was produced during John Hope's time as Regius Keeper. Catalogus arborum et fruticum in Horto Edinensi crescentium, 1778 was published in Edinburgh by Balfour and Smellie. This is arranged alphabetically by genus and with brief Latin descriptions and again carries no author's name but was also published in Hope's time. In 1794 Dixon and Co produced a catalogue. In the Edinburgh Library the

${ }^{1}$ The Nor' Loch (short for North Loch) was a dirty, marshy area on the north side of the Old Town of Edinburgh that was prone to flooding. During construction of the New Town the Nor' Loch was drained and now forms an urban park called Princes Street Gardens. 
leather spine currently carries Rutherford's name as author but Dixon was the author (it is possible that the catalogue was owned by Rutherford). In it, it states that plants are arranged "all the genera in alphabetical order, in manner of the Linnaean index, signature, pointing out the situation, duration, classes and order of each plant". The catalogue indeed follows the binomial system and for each taxon listed also includes common name and various abbreviations to denote dry stove, greenhouse, hardy, stove, annual, biennial, perennial or shrubby. The catalogue concludes with an index to English names.

The Library has a handwritten book, dated 1822, by William McNab (Curator of the Garden, 1810-1838) listing plants either recently planted at the new Inverleith site of the Royal Botanic Garden or which had been transported from the previous Leith Walk garden. While it is handwritten and therefore not a published catalogue it nonetheless gives an account of the plants growing in the garden in 1822 .

From 1778 there appears to be a gap of almost 100 years until the publication of the Departmental checklist of plants-Herbaceous of 1896. This contains no note or explanatory text whatsoever and plants are arranged alphabetically by genus along with authority and country of origin. There is also a List of Orchids for 31 March 1896, also arranged alphabetically by genus with authority and country of origin. There is no sign of any listings of trees and shrubs or glasshouse plants for this year.

The next catalogue is a List of Orchids in Cultivation, 1961 again with no text and with taxa arranged alphabetically by genus and with authority but no further information.

For the years 1986 to 1990 the Library has yearly Accession Books which list accessions received during the year plus an index to species, index to donors and index of donor addresses. Taxa are listed numerically by accession number in the order in which they were received and accession numbers assigned. The entries include as much or as little additional information as was supplied at the time of receipt. This ranges from full collection details (date, altitude, associated species, collector and collector number etc.) to absolutely nothing.

Catalogues, as understood today, were published in 1974, 1978, 1982, 1986, 1990, 1995, 2001 and 2006. Those for 1974 to 1986 appear in the same format and start with a very short introduction of about one page and then list plants arranged alphabetically by family. No authorities for the names are given and the only additional information is collector and collector number, where known. The catalogues of 1982 (see Fig. 9) and 1986 have an index to genera. The introduction to the 1974 Catalogue includes the following interesting note:

"The records of the plants growing in the Royal Botanic Garden, Edinburgh have evolved. It should not be forgotten that in 1683 James Sutherland published a list of at least 1500 plants in cultivation in the garden at that time. In 1896 Sir Isaac Bayley Balfour printed a list of plants for internal use - since then silence, except for seed lists! The late David Wilkie began the building up of a card index of the garden's content in the mid 1930s. After the Second World War a more intensive effort developed - at first 


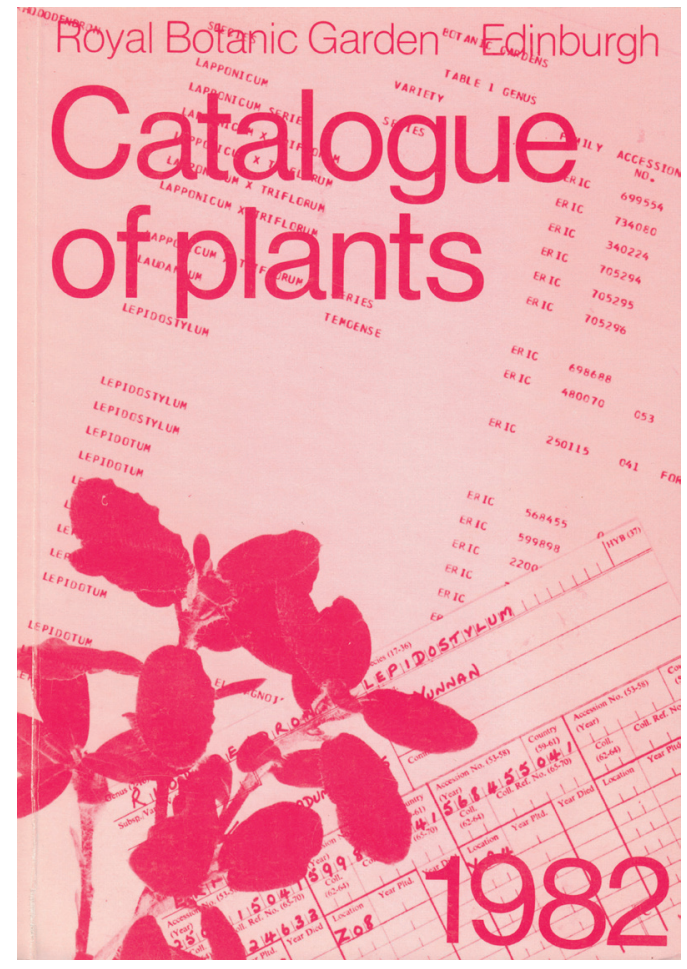

Fig. 9 Front cover of RBGE's Catalogue of Plants, 1982.

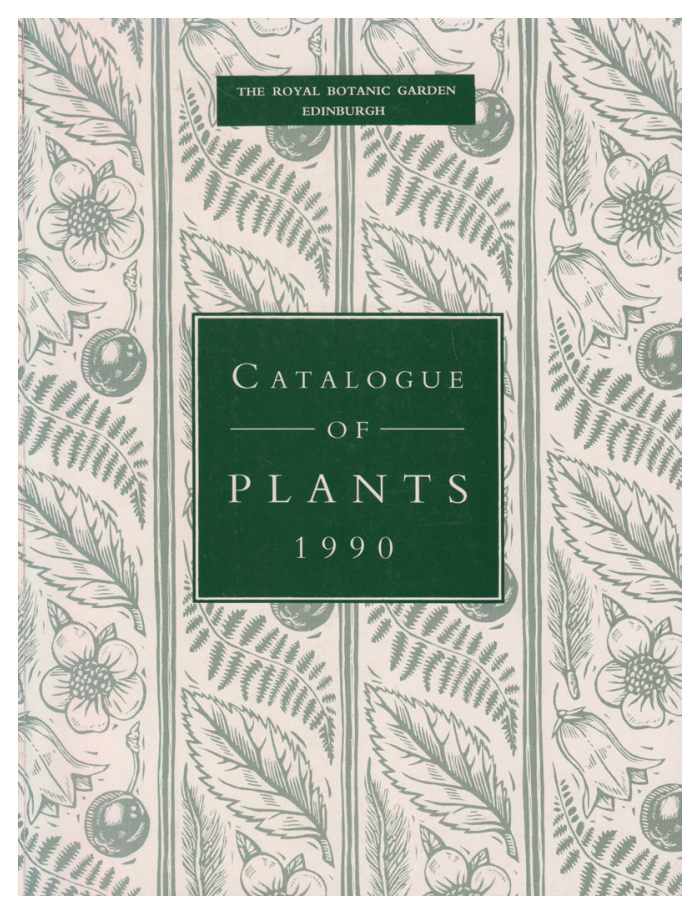

Fig. 10 Front cover of RBGE's Catalogue of Plants, 1990.

on cards, from 1970 onwards using a computer. The first printouts of all the living plant holdings came in 1972, and included material in the Garden in Edinburgh as well as the outstations, the Younger Botanic Garden, Benmore, Argyllshire and Logan Botanic Garden, Wigtownshire."

The Catalogue of Plants 1990 (Hamlet \& Maxwell, 1990) (see Fig. 10) is slightly larger than the previous A5 format and the front cover is of a different design. The contents, however, are identical except for the addition of an asterisk beside some taxa to denote wild origin.

With the adoption of a new plant records database, BG-BASE, in 1994, the potential for a more comprehensive catalogue grew considerably and the Catalogue of Plants 1995 (Walter et al., 1995) (see Fig. 11) shows a great improvement, in terms of information and publication quality, over the 1990 version. Fourteen introductory pages include an introduction, information on the four gardens (Dawyck Botanic Garden had been adopted in 1978), tables of collectors and expeditions, statistics of the Living Collections, summary of the RBGE acquisition policy, use of the Catalogue, BG-BASE, the plant records database, acknowledgements and caution (a disclaimer against any inaccurate data). The Catalogue follows in systematic order and includes authority, accession number, garden grown at, collection country (if wild collected), plus collector/ expedition name and collector's number. A few line drawings reproduced from recently 
RBGE-published floras (e.g. Flora of Bhutan and Flora of Arabia) are included and, after the Catalogue listing, short accounts of various scientific projects. The Catalogue finishes with an index to families and genera.

In 1996 the Garden published The Genus Rhododendron, Its classification and synonymy (Chamberlain et al., 1996) (see Fig. 12) which included both a list of species growing in the Collection and the list of names published up to the end of 1995. The 20 year period leading up to 1995 saw a large influx of Section Vireya rhododendrons coming into the Collection which, along with new material from China, added greatly to the already extensive Living Collection. As a result of the extensive existing material, plus the new material and recently published important monographs, produced mainly at Edinburgh and presenting a new system of classification (Chamberlain, 1982; Chamberlain \& Rae, 1990; Cullen, 1980; Judd \& Kron, 1995; Kron, 1993 and Philipson \& Philipson, 1986), the Garden was managing one of the most comprehensive Living Collections of rhododendrons in the world, containing about half of all the described rhododendron species. This along with the monographs led the Garden to decide to publish the book.

The book is arranged in four sections - an alphabetical list of all Rhododendron, Azalea and Ledum names, with their authorities, a list of all accepted names, with synonyms, arranged in taxonomic order, a list of accepted names in their Biological Recording Units (BRUs) and, finally, a list of all living collections of rhododendrons in

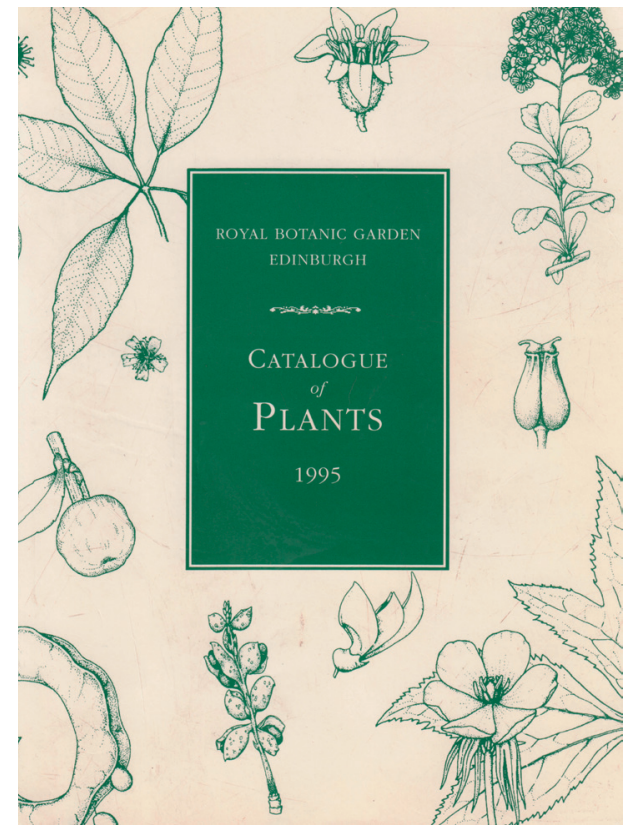

Fig. 11 Front cover of RBGE's Catalogue of Plants, 1995.

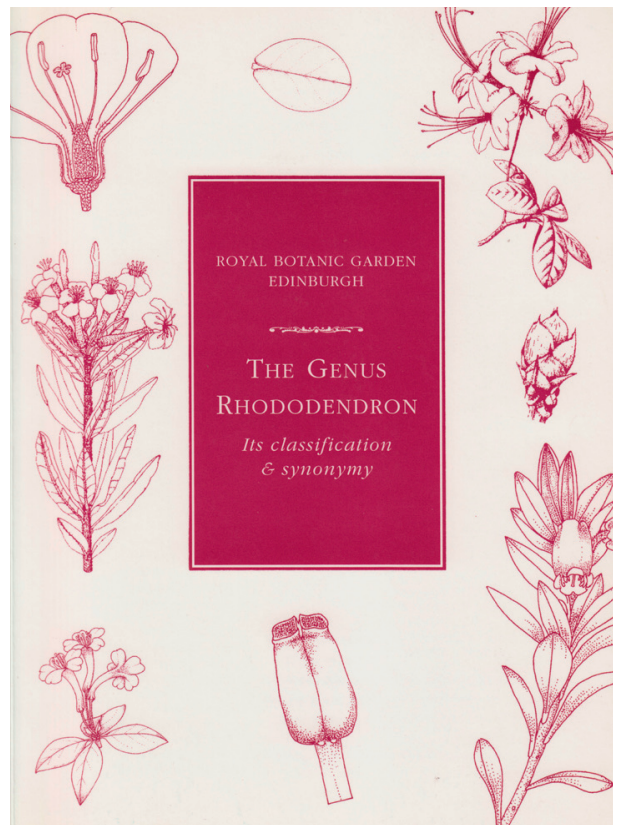

Fig. 12 Front cover of RBGE's The Genus Rhododendron, Its classification and synonymy, 1996. 
cultivation at the four gardens of the RBGE together with their country of origin and collection details.

The Catalogue of Plants 2001 (Govier et al., 2001) (see Fig. 13) demonstrates another great improvement in quality and quantity of information. The cover has a bold close up photograph of the bright yellow flower of Inula racemosa, giving rise to the familiar name of the Catalogue from frequent users as 'the yellow catalogue'. There are 90 pages of introductory text with collection statistics, essays, information, histories and more. The Catalogue itself is 566 pages in length and plants are listed systematically by family and then alphabetically by genus and species within genus. Each family listing starts with a table listing the number of genera and species of that family in the world and the number of genera and species in the Living Collection, followed by the number of accessions and plants in the Living Collection. Each entry includes species name, authority and then a list of the accessions and the name of the garden in which they grow. This is followed by country of collection (if wild collected) and collector or expedition name and collector/expedition number. Line drawings from recent flora projects are included within the text along with 'vignettes' of current projects. In the centre there are 16 pages of photographs of plants arranged by various topics.

The Catalogue of Plants 2006 (Rae et al., 2006b) (see Fig. 14) is very similar in style to the 2001 Catalogue and the front cover is of the fern Asplenium nidus var. nidus ('the green catalogue'). The content of the Catalogue is as follows:

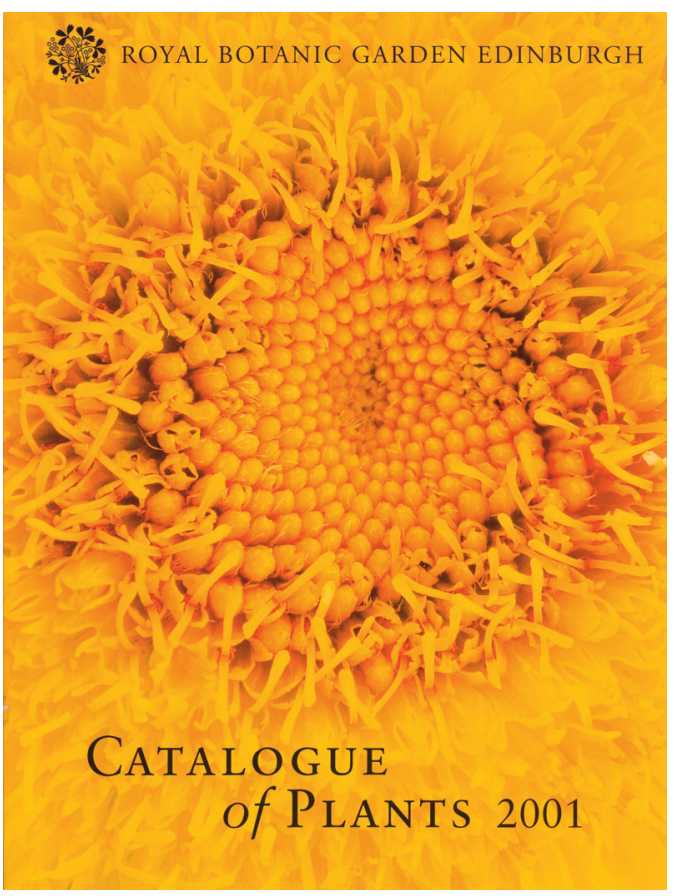

Fig. 13 Front cover of RBGE's Catalogue of Plants, 2001.

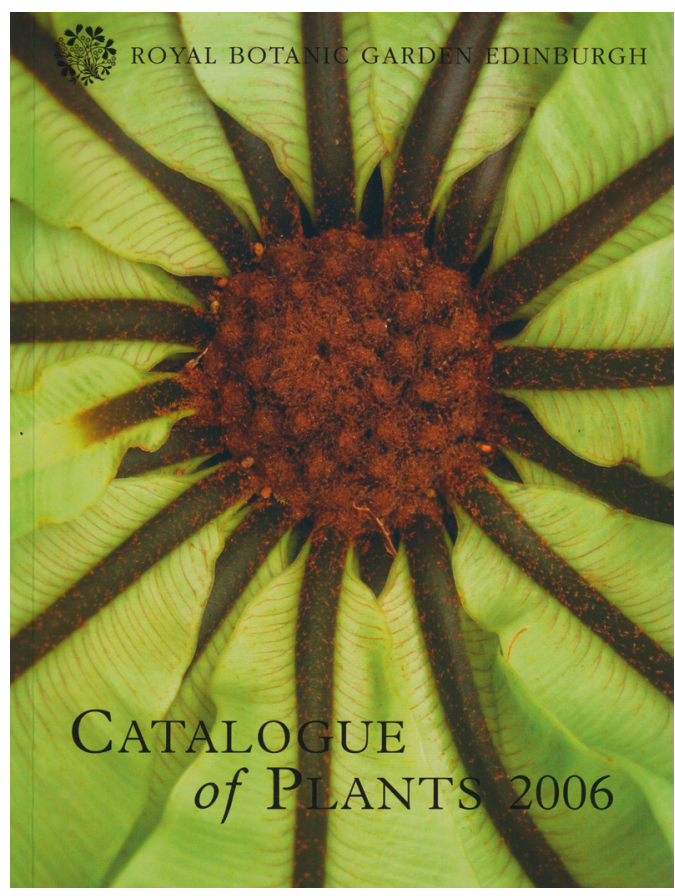

Fig. 14 Front cover of RBGE's Catalogue of Plants, 2006. 
- Overview of the Living Collection at RBGE which includes numerous tables and statistics about the collection (for example Table 1. The Living Collection at RBGE on 1 August 2006, see Fig. 15)

- Development of the new Collection Policy (Rae et al., 2006a) including a description of the process and synopsis of the five chapters and seven appendices

- RBGE's Strategy for Science, written by Professor Mary Gibby, Director of Science and describing how the Science Strategy had been designed to deliver biodiversity science to underpin conservation

- Developments at the four Gardens written by the five garden Curators (two at Edinburgh and one at each of the Regional Gardens) and describing new plantings and projects at each of the gardens since publication of the 2001 Catalogue

- Some historic notes. This chapter included three contributions describing noteworthy historic events. The first covers the history and development of the Rock Garden from its first creation 135 years ago, through its redevelopment in 1908 by Isaac Bayley Balfour, to the present day. The second, titled the 'Beech Hedge - a century of history', describes the magnificent beech hedge that forms the backdrop to the herbaceous border and the last, 'Dawyck celebrates its silver anniversary', briefly describes Dawyck Botanic Garden's history and, especially, developments since it was acquired by RBGE 25 years ago

- 'Recent major projects' describes two important, recently completed projects - the redevelopment of the Temperate Palm House and the Queen Mother's Memorial Garden

- 'Quarantine and Nursery' includes descriptions of two vitally important facilities at the Garden which are seldom seen by visitors but which are vital for the efficient function of the Living Collection

- 'Phenology at RBGE' covers the initial stages and on-going development of the Garden's various phenological projects

- 'International training and capacity building' describes projects in Bhutan, Chile, Nepal, Peru, Lao People's Democratic Republic, Soqotra, Turkey and Vietnam

- 'Recording the Living Collection' describes recent developments in the practices and techniques involved in plant records

- 'Access to the Living Collection' provides guidance to scientists and others wanting access to plant material

- 'How to use this Catalogue' describes the layout and use of the Catalogue, along with abbreviations used and an explanation of a single entry (Fig. 16)

- Catalogue listings follow for bryophytes, fern allies, ferns, gnetophytes, conifers ginkgophytes, cycads, dicotyledons and monocotyledons

- Vignettes - amongst the Catalogue listings short, boxed insights are given of 26 projects that use the Living Collection for various purposes

- Index - while the Catalogue is presented taxonomically the index provides an alphabetic listing with page numbers of families and genera 


\begin{tabular}{|c|c|c|c|c|c|c|c|c|c|}
\hline \multirow[t]{2}{*}{ Major taxon } & \multicolumn{2}{|c|}{ Families' } & \multicolumn{2}{|c|}{ Genera' } & \multicolumn{2}{|c|}{ Species $^{2}$} & \multirow[t]{2}{*}{$\operatorname{Taxa}^{3}$} & \multirow[t]{2}{*}{ Accessions ${ }^{4}$} & \multirow{2}{*}{$\begin{array}{l}\text { Plant } \\
\text { records }\end{array}$} \\
\hline & Num. & $\%$ of world ${ }^{6}$ & Num. & $\%$ of world ${ }^{6}$ & Num & $\%$ of world ${ }^{6}$ & & & \\
\hline Bryophytes & 13 & $8 \%$ & 16 & $1 \%$ & 16 & $1 \%$ & 16 & 18 & 19 \\
\hline Fern allies & 5 & $100 \%$ & 8 & $80 \%$ & 77 & $6 \%$ & 82 & 154 & 190 \\
\hline Ferns & 27 & $69 \%$ & 145 & $54 \%$ & 510 & $6 \%$ & 552 & 1,202 & 1,69 \\
\hline Gnetophytes & 3 & $100 \%$ & 3 & $85 \%$ & 14 & $15 \%$ & 16 & 33 & 47 \\
\hline Conifers & 8 & $89 \%$ & 71 & $97 \%$ & 462 & $69 \%$ & 897 & 4,374 & 16,122 \\
\hline Ginkgophytes & 1 & $100 \%$ & 1 & $100 \%$ & 1 & $100 \%$ & 2 & 14 & 42 \\
\hline Cycads & 4 & $100 \%$ & 9 & $82 \%$ & 32 & $22 \%$ & 32 & 50 & 58 \\
\hline Dicots & 214 & $68 \%$ & 2,097 & $16 \%$ & 10,970 & $4 \%$ & 14,299 & 27,118 & 38,257 \\
\hline Monocots & 67 & $69 \%$ & 711 & $19 \%$ & 3,597 & $5 \%$ & 4,465 & 8,232 & 9,191 \\
\hline Unknown & 2 & - & 2 & - & 2 & - & 3 & 67 & 33 \\
\hline Collection total & 344 & $49 \%$ & 3,063 & $16 \%$ & 15,681 & $5 \%$ & 20,364 & 41,262 & 65,650 \\
\hline
\end{tabular}

For comparative purposes, totals from the Catalogue 2001 were as follows:

\begin{tabular}{|c|c|c|c|c|c|c|c|c|c|}
\hline 2001 Catalogue total & 345 & $49 \%$ & 3,063 & $16 \%$ & 15,420 & $5 \%$ & 20,390 & 41,331 & 65,632 \\
\hline
\end{tabular}

The figures above record totals for the 'whole' collection including plants cultivated offsite as part of the Garden's International Conifer Conservation Programme (ICCP) and plants held in the seed store (genebank). The totals below show the number of plants in RBGE's four Gardens only.

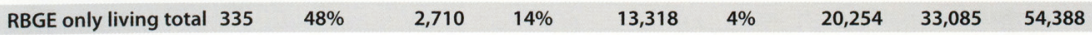

Fig. 15 Collection statistics from RBGE's Catalogue of Plants, 2006.

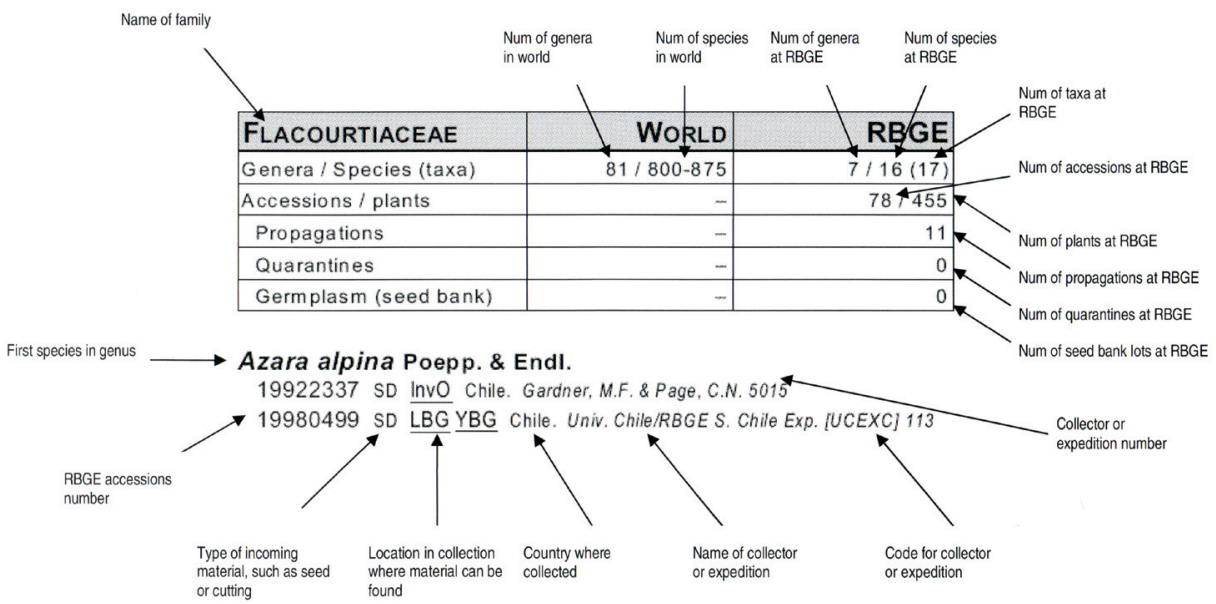

Fig. 16 Figure from RBGE's Catalogue of Plants, 2006 showing how to interpret entries in the Catalogue.

- The Catalogue concludes with illustrations of paintings by two talented, versatile and prolific botanical artists (Mary Mendum and Eve Bennett) both of whom had died since publication of the 2001 Catalogue.

Despite the time involved in stocktaking, compilation, editing and checking, not to mention the cost, staff at RBGE believe that there is considerable value in producing a published Catalogue of Plants at regular intervals and will continue to do so. 


\section{ACKNOWLEDGEMENTS}

The author acknowledges with grateful thanks the help given by Timothy Walker, Horti Praefectus of the Oxford University Botanic Garden and Harcourt Arboretum, in supplying the images for Figs. 4 and 5. The author is also very grateful for help given by Graham Hardy, from RBGE's Library, in connection with RBGE's historic catalogues.

\section{REFERENCES}

APLIN, DAVID, LININGTON, SIMON \& RAMMELOO, JAN (2007). Indices Seminum: are they really worth the effort? Sibbaldia: the Journal of Botanic Garden Horticulture, 5, 93-107.

CHAMBERLAIN, D.F. (1982). A revision of Rhododendron. II Subgenus Hymenanthes. Notes from the Royal Botanic Garden Edinburgh, 39(2), 209-486.

CHAMBERLAIN, D.F. \& RAE, S.J. (1990). A revision of Rhododendron. IV Subgenus Tsutsusi. Edinburgh Journal of Botany, 47(2), 89-200.

CHAMBERLAIN, DAVID, HYAM, ROGER, ARGENT, GEORGE, FAIRWEATHER, GILLIAN \& WALTER, KERRY (1996). The Genus Rhododendron, Its classification and synonymy. Royal Botanic Garden Edinburgh.

CULLEN, J. (1980). A revision of Rhododendron. I Subgenus Rhododendron sections Rhododendron and Pogonanthum. Notes from the Royal Botanic Garden Edinburgh, 39(1), $1-207$.

GERARD, JOHN (1633). The Herball or Generall Historie of Plants, Gathered by John Gerard. Very much Enlarged and Amended by Thomas Johnson of London. London.

GOVIER, REBECCA et al. (2001). Catalogue of Plants 2001. Royal Botanic Garden Edinburgh.

HAMLET, H. \& MAXWELL, S. (1990). Catalogue of Plants 1990. Royal Botanic Garden Edinburgh.

JUDD, W.S. \& KRON, K.A. (1995). A revision of Rhododendron sections Sciadorhodion, Rhodora and Viscidula. Edinburgh Journal of Botany, 52(1), 1-54.

KRON, K.A. (1993). A revision of Rhododendron section Pentanthera. Edinburgh Journal of Botany, 50(3), 249-364.

LIVING COLLECTIONS DEPARTMENT OF THE ARNOLD ARBORETUM (2003). The Arnold Arboretum of Harvard University, Inventory of Living Collections 2003. Arnold Arboretum.

MCALLISTER, HUGH, MARRS, ROBERT \& CUNNINGTON, PETER (1998). Index Nessensis, Catalogue of the Plant Collections at Ness Botanic Gardens. National Museums and Galleries on Merseyside, Liverpool Museum.

PHILIPSON, W.R. \& PHILIPSON, M.N. (1986). A revision of Rhododendron. III. Subgenera Azaleastrum, Mumeazalea, Candidastrum and Herorhodion. Notes from the Royal Botanic Garden Edinburgh, 44(1), 1-23.

RAE, DAVID et al. (2006a). Collection Policy for the Living Collection. Royal Botanic Garden Edinburgh. 
RAE, DAVID et al. (2006b). Catalogue of Plants 2006. Royal Botanic Garden Edinburgh.

ROBERTSON, FORBES W. (2001). James Sutherland's Hortus Medicus Edinburgensis (1683). Garden History - Journal of the Garden History Society, 29(2), 121-151.

UNIVERSITY OF OXFORD (1999). A catalogue of plants growing in the University of Oxford Botanic Garden and Harcourt Aboretum. Oxford. UK.

WALTER, KERRY S., CHAMBERLAIN, DAVID F., GARDNER, MARTIN F., MCBEATH, RONALD J.D., NOLTIE, HENRY J. \& THOMAS, PHILIP (1995). Catalogue of Plants 1995. Royal Botanic Garden Edinburgh.

WOLLENBERG, BERT J.W. VAN DEN et al. (1992). Utrecht University Catalogue of Plant Collections, 1992. Botanic Gardens, Utrecht, The Netherlands. 
